\title{
戦後復興期広島の観光景観とその語り \\ LANDSCAPE OF TOURISM AND ITS ORAL EXPLANATIONS IN HIROSHIMA CITY IN THE RECONSTRUCTION PERIOD
}

\author{
千代 章一郎*, 横 山 尚** \\ Shoichiro SENDAI and Hisa YOKOYAMA
}

\begin{abstract}
This paper aims to clarify the transformation of the landscape of tourism just after the World War II through the oral explanations by the tour guides in the reconstruction period of the sightseeing bus tours in Hiroshima. Analyzing the guide texts and the interview to the tour guides at that time, we can find out the process of the connection of the various information; the tradition of Hiroshima before the war, the historical evidences in the wartime and the postwar rehabilitation. That is to say, the atom-bombed city Hiroshima in the beginning intended to be the 'peace' city, integrating the landscapes of tourism of the various times and spaces.
\end{abstract}

\author{
Keywords : Urban landscape, Landscape of tourism, Peace city, Sightseeing bus tour, View, \\ The Seto Island Sea \\ 都市景観、観光景観、平和都市、定期観光バス、眺望、瀬戸内海
}

\section{1.はじめに}

\section{1-1. 研究の主题と目的}

本研究は、都市における景観生成という主題について、都市観光 を通して考察することを目的としている。所謂「日常景」とは対照 的な、都市観光を通して表れる「観光景観」もまた、ある意味では 都市のアイデンティティの一面を表していると考えられる。とりわ け近代の観光を一種の「疑似体験」の享受と見なすのではなく1)、 観光事業者（ホスト）と観光客（ゲスト）との相関として捉え直す ことで、人間が体験する場所の現前性-再現性の問題について考察し 2)、都市のアイデンティティの形成を再考してみたい。

これまでの筆者の研究では、広島市における定期観光バス ${ }^{3)}$ を研 究対象とし、その運行開始時 (昭和 29 年) から現在までの運行系統 （バス観光ルート）を全て復元し、それらの運行系統の変更要因に ついて考察を加えた ${ }^{4)}$ 。また、その運行系統の変化と同時に移り変 わる眺望対象 ${ }^{5}$ についても、案内の形式から分析を行った ${ }^{6)}$ 。

そこで本稿では、広島市において定期観光が始まる戦後復興期に 関して、バスガイドによって案内される「語り」の内容から、主要 眺望対象の観光景観の生成とその変容の要因について考察すること を目的とする。

一般的に、定期観光バスは毎日定時に運行され、予約なしで比較 的自由に利用できるといら利点を持っている。定期観光バスでは、
る7)。また、観光地ではバスから下車してその場所を自分で歩きな がら、見る、聞く、触るなどの体験をする。そして、これらの一連 の観光行動には、殆どバスガイドによる観光案内が伴い、眺望対象 の歴史や由来、特徵、呼称などの詳細な情報を聞きながら、観光客 は観光景観を形成する。とくに戦後復興期には広島市の定期観光バ スは、戦後復興の姿を見るために宮島観光と共に社内旅行や修学旅 行などで盛んに用いられた ${ }^{8)}$ 。したがって、定期観光バスにおける 「観光景観」は「語り手」と「聞き手」の相互作用によって生成さ れると考えられるが、本研究では特にそうした観光景観生成の最初 の契機であるバスガイドによる「語り」に注目したい。

観光景観に関する既往の研究として、観光景観画像910)や名所図 絵 ${ }^{11)}$ に関する定量的分析がある。また観光地に関するテキスト分析 12) 13) や景観生成の研究 14)、あるいはその心象的景観に関する研究15) がある。それらに対して本稿は、観光事業者（ホスト）によって提 供される観光景観を視覚像と意味内容の両面から捉え、その生成変 容を明らかにしようとするものである。

\section{1-2. 研究方法}

本稿では、広島バス株式会社（以下、「広島バス」）のバスガイド が広島定期観光バスに乗務する前に案内内容を暗記するための基礎 資料である「ガイドテキスト」を収集し、一次資料とした。また、 バスガイド経験者へのインタビューを行い、その聴取データを共に 一次資料とした。
* 広島大学大学院工学研究科社会環境システム専攻 助教授 - 博士 (工学)

**広島大学大学院工学研究科社会環境システム専攻 大学院生・修士 (工学)
Assoc. Prof., Graduate School, Hiroshima Univ., Dr. Eng.

Graduate Student, Graduate School, Hiroshima Univ., M. Eng. 
ガイドテキストは、運行系統の変更や都市景観の変容、観光客の 要望に応じて、バスガイドによって新聞や文献資料、観光地での調 査などをもとに、時事に合わせて改訂される。その間隔はおよそ一 年である ${ }^{16)}$ 。実際の案内では、バスガイドはガイドテキストの内容 をある程度演出を加えて改変している。しかし、バスガイドへのイ ンタビューによれば、ガイドテキストはバスガイドらにとって基本

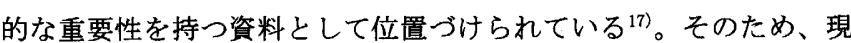
在ではガイドテキストは企業資産としてバスガイド退職時にバス会 社に返却される。バス会社に保管されているガイドテキストは 5 部 であり、最も古いテキストは昭和 48 年発行である ${ }^{18)}$ 。しかし、それ 以前のガイドテキストが個人所有されていることが判明した（昭和 37 年発行 $\left.{ }^{19}\right)$ 。

一方、 $\mathrm{N}$ 女史と S 女史の二名の広島バスのバスガイド退職者にイ ンタビューを行った ${ }^{20)}$ 。ガイドテキストが発行された昭和 37 年と前 後する時期について、昭和 37 年や昭和 48 年のテキストとの相違点 を確認するかたちでインタビューを行い21)、戦後復興期における眺 望対象やそれらに対する案内内容についての聴取データを得た。

したがって本稿では、定期観光バス事業が開始される昭和 29 年か ら、高度成長期のガイドテキストが存在し、南北の運行系統が定着 する昭和 48 年以前までを戦後復興期とし、昭和 37 年のガイドテキ ストを基準にその前後を合わせ、3 段階に区分した。

本稿では、それらの一次資料と時期区分に基づいて、まず運行系 統を復元してその概要を述べ (2.)、案内の特に多い眺望対象を主要 眺望対象として抽出し、その観光景観について写真資料などを用い て周辺環境を含めた視覚像を把握する ${ }^{22)}$ (3.)。次に、ガイドテキス 卜及びインタビュー聴取データからそれらの観光景観に対する案内 内容の変化について考察する (4.)。

\section{2. 㯰行系統变遈の概要（表 1-1 参照）}

2-1. 第一段陼 : 昭和 29 年 36 年

広島城 $\rightarrow$ 原爆ドーム・平和記念公園 $\rightarrow$ (瀬戸内海) $\rightarrow$ 比治山 - 御便殿跡

（但し（）内は下車しない眺望対象）

この時期では、広島城・原爆ドーム・比治山を経由する南北の運行系 統の原型がつくられる。その他に、戦前からある寺社や戦争に関連する 施設を比較的多く経由する。

\section{2-2. 第二段階 : 昭和 37 年}

(世界平和記念聖堂) $\rightarrow$ (縮量園) $\rightarrow$ 広島城 $\rightarrow$ 原爆ドーム・平和記念公 園 $\rightarrow$ 広島空港 $\rightarrow$ 比治山展望台（但し（）内は下車しない眺望対象） この時期では、瀬戸内海まで南下せず、市街地を東西に移動する運 行系統となる。戦後復興整備による市街地の施設や、市街地西部に位 㯰する新設の広島空港を経由し、他の段階で経由する瀬戸内海沿岸部 の港は経由しない。

\section{2-3. 第三段倩 : 昭和 38 年 47 年}

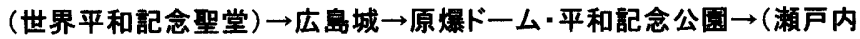
海 $) \rightarrow$ (東洋工業宇品工場 $) \rightarrow$ 比治山展望台（但し（）内は下車しな (眺望対象)

この時期には、南北移動に加え瀬戸内海沿岸を東に移動する運行系 統となる。前段階までとほぼ同様の市街地の施設を経由する他に、バス は瀬戸内海沿岸部に新設された東洋工業の近辺を走行する。

\section{3. 主要䁖望対象の景钼変容（表 1-1 及び表 2 参照）}

\section{3-1. 世界平和祀念整堂}

第一段階には、昭和 29 年 6 月に竣工したこの聖堂は新奇性の高 い建物で話題性が高く、また周辺の建物に比べ高層で遠方からも見 えた可能性があるにも関わらず、公的な機関ではなかったため聖堂 近くを走行せず、眺望対象とならなかったと思われる23)。

そして第二、第三段階には眺望対象となっている。第二、第三段 階共に、観光客は橋の上で走行中の車内から川（京橋川）向こうに 見ていた。バスガイド経験者へのインタビューによると、周辺の住 宅群に比べ高層であり、また建物上部の十字架が目印となるため、 観光客にもよく見えていた（写真 1$)$ 。

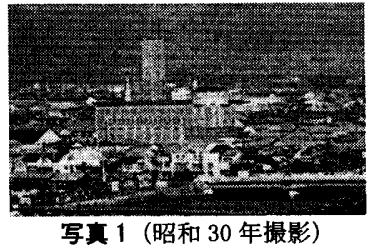

\section{3-2. 缩最㕑}

第一段階には昭和 26 年に復興整備された縮景園の付近を走行す る運行系統であるにも関わらず、眺望対象とならなかった。事業者 へのインタビューによると、休園日がある施設は、毎日運行する定 期観光バスにおいては下車場所とすることができなかった。おそら くこの時期の縮景園もその理由で下車案内はされなかったと思われ る。また、車内から見ても園内の様子は確認できないため、車内か らの案内を避け、他の眺望対象の案内を優先していたと推測される。

しかし第二段階には、縮景園西側道路を走行中の車内からの案内 のみが行われる。観光客は庭園の内部は見えないが、昭和 34 年に完 成した隣接する「モダンな建物」広島県立図書館の案内と共に、そ の周囲に縮景園の樹木が茂っている様子を車内から見ていた（写真 2)。この段階には、案内地点となった道路から県立図書館までは高 い建物はなく図書館の奥に縮景園の樹木が見えた。

第三段階には、バスガイドへのインタビューによると、おそらく 世界平和記念聖堂を目印にして、その背後に縮景園を見せる方向に 変わる ${ }^{24)}$ 。昭和 43 年図書館の西側に広島県立美術館が建てられた ことにより、図書館、縮景園の樹木は共に隠され、第二段階の方向 からの案内は中止されたと考えられる（写真 $3:$ 広島県立美術館の 背後に県立図書館と縮景園の樹木)。第二段階以降、庭園内部の幾つ かの建物が復元されていることから、内部の様子は変化していたと 考えられるが、下車しなかったため周辺からの眺望のみで、その樹 木の茂っている様子はあまり変化しなかったと思われる。

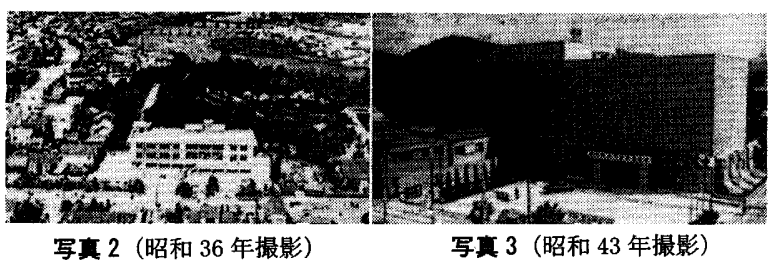

\section{3-3. 広岛城}

第一段階から第三段階まで眺望対象となり、どの段階でも城内で 下車をして、大本営跡や天守閣、第二段階以降には広島護国神社も 
新設され、それらを見ながら移動する。第一段階の初めには天守閣 の復元されておらず、天守閣の石垣のみであった時期もあった（写 真 4)。しかし、天守閣がなくても城跡というその場所の意味を重要 視して下車案内がされていたものと考えられる。その後復元工事中 には、天守閣の大きさを思わせる大規模な工事を眺めていたと考え られる。また、内堀内側にある通信司令室（防空壤）も眺望対象と
なっていた。 昭和 33 年には「広島復興大博臨会」開催に合わせて、 天守閣の復元工事が完了しており、第二、第三段階では、走行中の車内 から石垣と内堀内側の広島護国神社を眺め (写真 5)、内堀内側で下 車をして、歩いて大本営跡、天守閣の近くまで行く。そして、観光 客のみが自由に天守閣などを見学する。そのために、高層建築物で あるにもかかわらず、外からの特別な案内はされない。

表 1 運行系統と主要眺望対象の案内内容（筆者作成）

\begin{tabular}{|c|c|c|c|c|}
\hline \multicolumn{2}{|c|}{ 哖量 } & 筑一段階: 昭和29年〜 $\sim 36$ 年 & 勧二段倩; 昭和37年 & 第三段階: 昰 \\
\hline & & 进隹 & 承耕の & \\
\hline \multicolumn{2}{|c|}{ 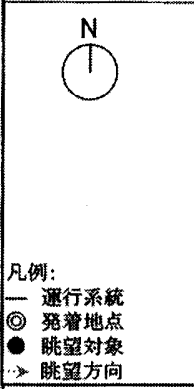 } & 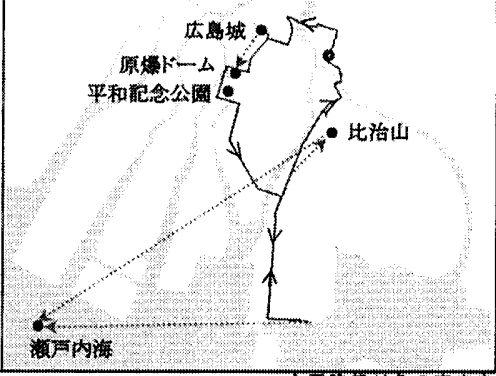 & 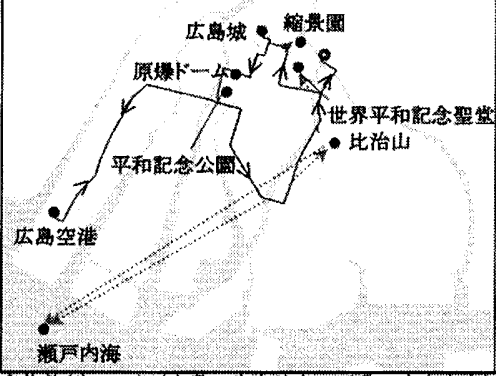 & 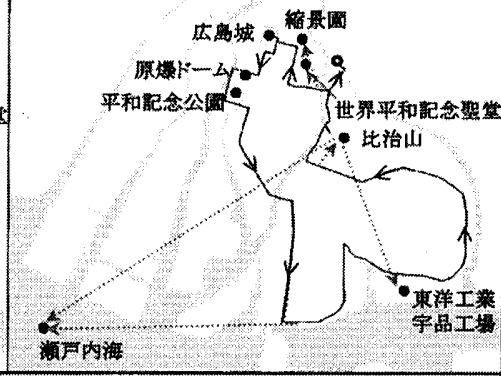 \\
\hline \multirow{2}{*}{\multicolumn{2}{|c|}{ 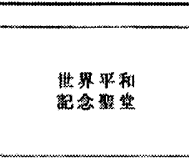 }} & 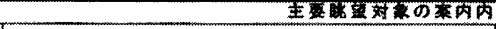 & 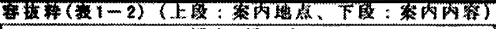 & \\
\hline & & [跑速加了] & 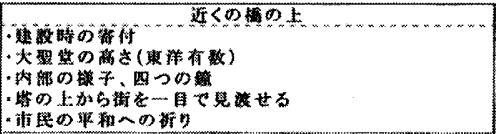 & 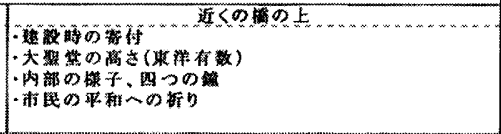 \\
\hline \multicolumn{2}{|c|}{ 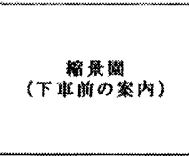 } & [配速圠し] & 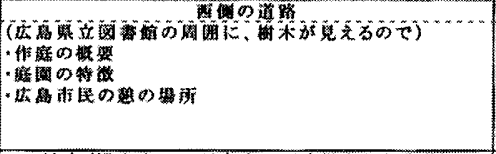 & 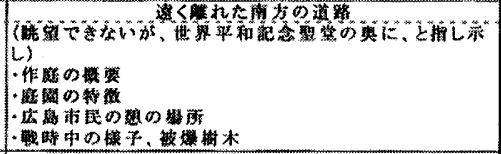 \\
\hline \multicolumn{2}{|c|}{ 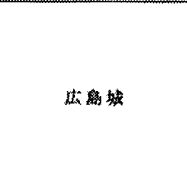 } & 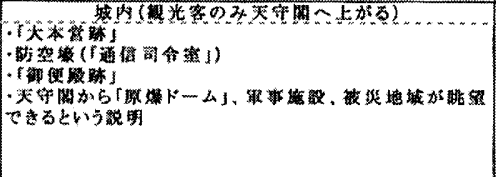 & 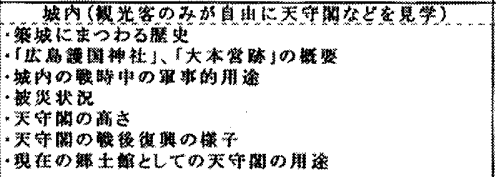 & 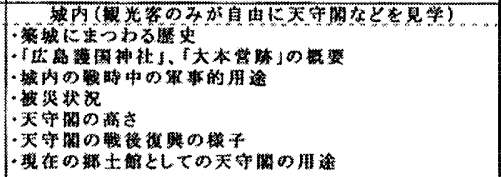 \\
\hline \multicolumn{2}{|c|}{ 湶嵝ドーム } & 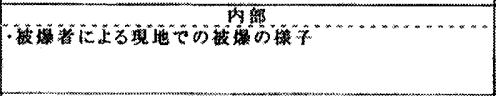 & 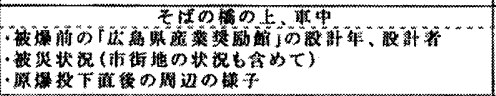 & 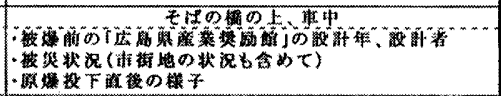 \\
\hline \multicolumn{2}{|c|}{ 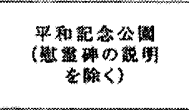 } & 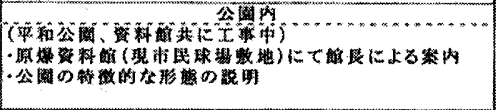 & 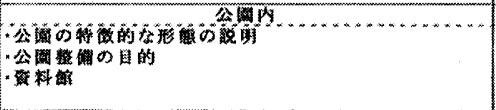 & 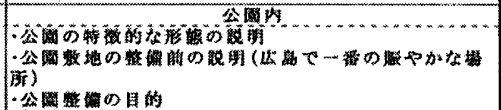 \\
\hline \multicolumn{2}{|c|}{ 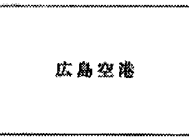 } & 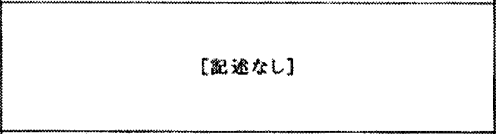 & 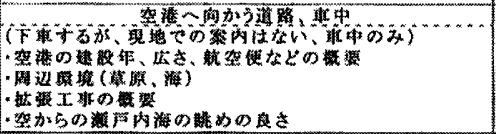 & [鼠速机し] \\
\hline \multicolumn{2}{|c|}{ 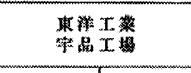 } & [紀逢なし] & 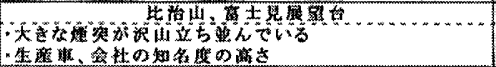 & 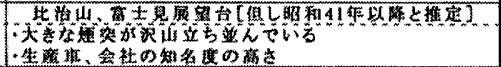 \\
\hline \multirow[b]{2}{*}{ 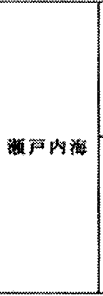 } & 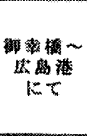 & 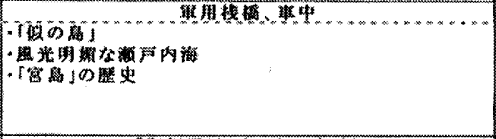 & 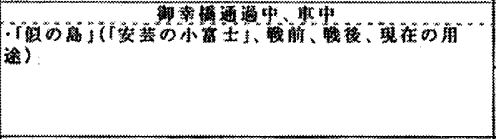 & 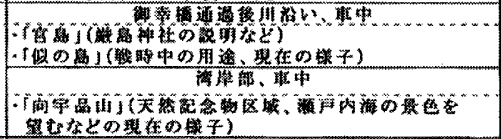 \\
\hline & 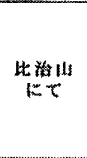 & 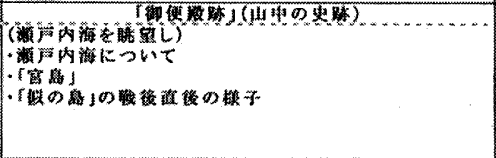 & 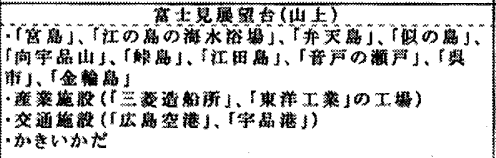 & 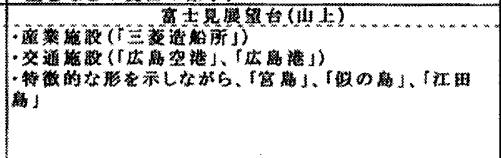 \\
\hline \multirow{3}{*}{\multicolumn{2}{|c|}{ 地綃㫛 }} & 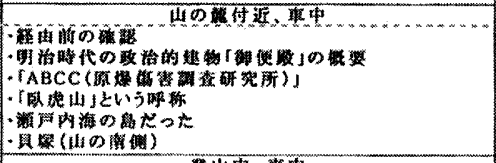 & 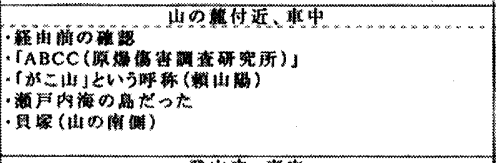 & 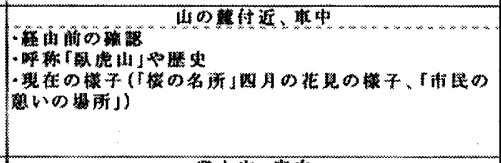 \\
\hline & & 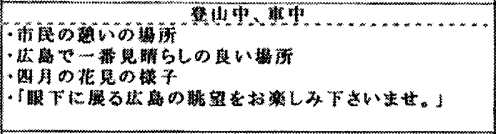 & 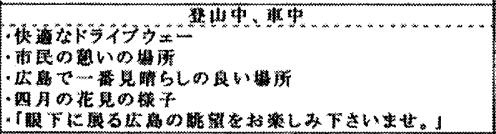 & 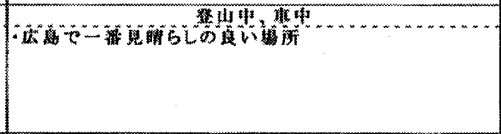 \\
\hline & & 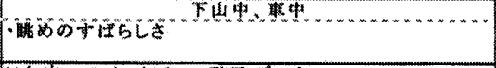 & 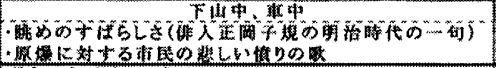 & 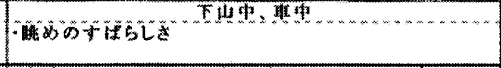 \\
\hline \multicolumn{2}{|c|}{ 新驽料 } & 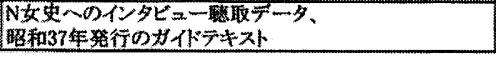 & 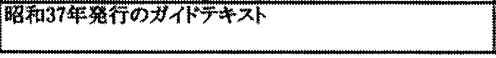 & 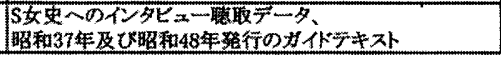 \\
\hline
\end{tabular}




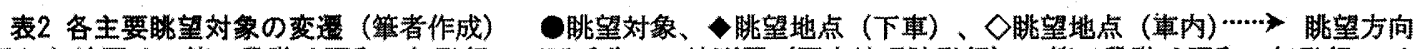
（表中に示した地図は、第一段階は昭和 32 年発行二万五千分の一地形図（国土地理院発行）、第二段階は昭和 42 年発行一万分の一地形 図 (広島市発行)、第三段階は昭和47年発行三万五千分の一地形図（国土地理院発行）をもとに篗者が加篗したものである。）

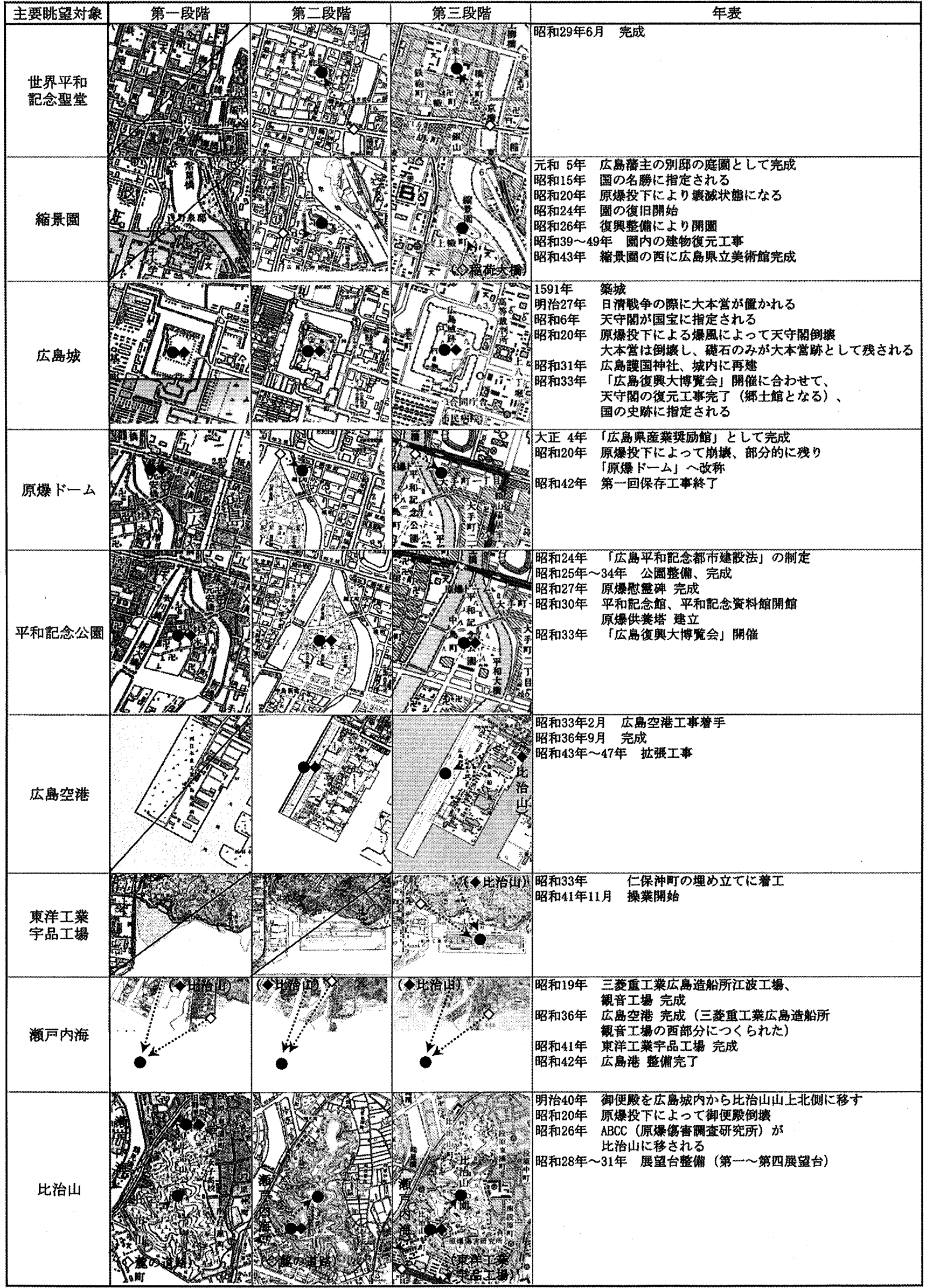




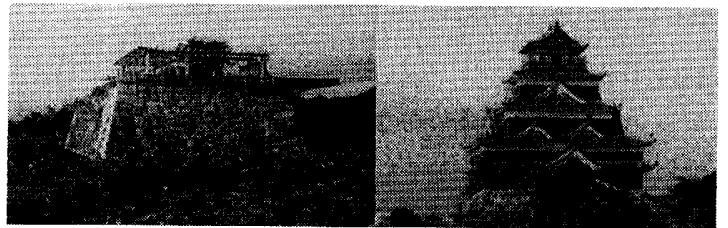

写兵 4 (昭和 32 年撮影)

写共 5 (昭和 33 年撮影)

\section{3-4. 原㩧ドーム}

原爆投下によって崩壊した広島県産業奖励館はいつからか「原爆 ドーム」と呼ばれるようになった 25)。第一段階には保存工事が始ま っていないが、直接原爆ドームの西側までバスで行き、そこで観光 客は下車をして、ドーム内へ入って行く（写真 6)。この段階の初期 にはまだドーム周辺に戦後にできたバラックが密集していた。

第二段階からは、バスガイドへのインタビューによると、保存状 態の悪さによる危険性から内部に入らず、原爆ドームそばのドーム がほぼ正面から見える橋の上の停車しているバスの車内から眺めた

(写真 7)。第三段階の途中から保存工事が開始されたため、建物全 体に工事のための足場が組まれ、覆いがされていた時期もあった。

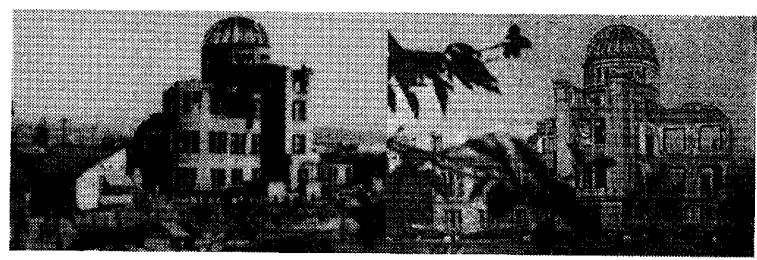

写真 6 (昭和 29 年撮影)

写基 7 (撮影年不明)

\section{3-5. 平和粑念公圆}

昭和 25 年に整備が始まる平和記念公園は、どの段階でも公園内で 下車して、公園内を歩きながら、慰霊碑や施設を見る。

第一段階の初期、昭和 33 年までは公園内には戦後に建てられたバ ラックが建ち並んでいた。その中に原爆慰霊碑や原爆供養塔があり、 それらを見て回った（写真 8)。そして、公園整備が進むにつれてそ れらは取り壊され、その後に植樹される（写真 9 )。昭和 30 年以降 は、完成した平和記念館、平和記念資料館内の見学も行っていた。 その後、徐々に木々は成長し、慰霊碑の数も増えていく。

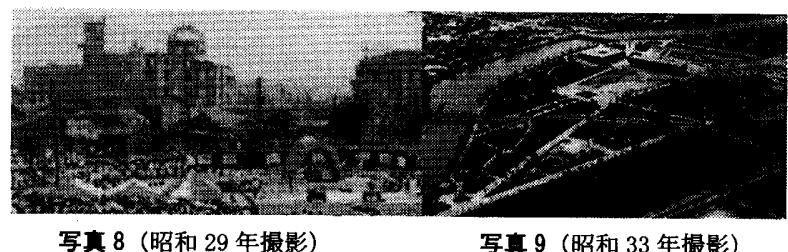

\section{3-6. 広岛空港}

広島空港は、完成直後の昭和 37 年の第二段階のみで下車案内され る ${ }^{26)}$ 。空港まで南下する途中に案内され、その後現地で下車をして 観光客は自由行動をし、空港ビルなどを見学するが、現地での案内 はされない。当時は緑の草原の中に $1200 \mathrm{~m}$ の滑走路と空港ビルがあ り、その周辺は三菱重工業観音工場などがあるが、高い建物は殆ど 無かった（写真 10）。バスガイドへのインタビューによると、展望 デッキがあり瀬戸内海も見えたが、高さはあまり高くなかった。
また比治山の展望台から、第二段階には下車案内と共に遠方であ るにも関わらず、血山の向こうに広島空港があると示される（写真 11:右端に見える山が皿山)。このことを地図上で確認する限りでは、 おそらく細長く続く滑走路と草原が血山によって一部隠されてはい たが、山の右側に確認できたと考えられる。

バスガイドへのインタビューによると、交通量が多いため、空港 への行き䚻りに渋滞することが多くなり、時間通りに運行すること が困難になったため、第三段階には経由が中止された ${ }^{27)}$ 。しかし、 下車しないにも関わらず、第三段階では比治山から方向を示して案 内されていた（写真 11）。

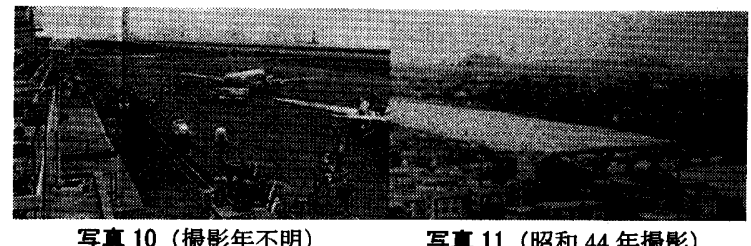

\section{3-7. 東洋工菜宇品工堨}

第一段階には、敷地の埋め立て工事中で工場が完成していないた めに、案内されない（写真 12）。

第二段階には操業は開始していないが、話題性が高かったため、 第二段階で東洋工業の案内内容を含んだテキストが用意されていた が ${ }^{28)}$ 、第三段階の初期の昭和 $40 、 41$ 年までは本格的な操業前であっ たため、案内されなかったようである。

その後、昭和 41 年 11 月に操業開始をしてからは、運行系統から 判断して工場近くを通りながら案内されていたと思われる。少なく とも下車した比治山の展望台から、立ち並ぶ煙突を目印にして眺望 していた（写真 13 : 操業開始直後の写真であり煙突はまだない)。

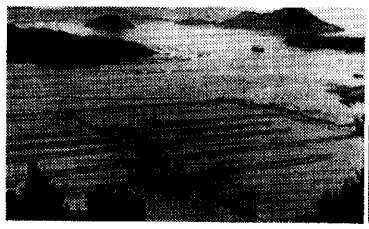

写真 12 (昭和 37 年撮影)

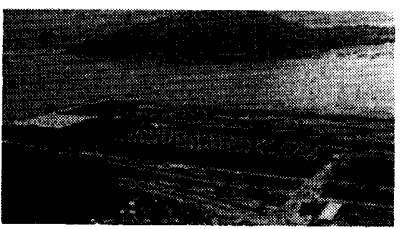

写兵 13 (昭和 42 年撮影)

\section{3-8. 瀬戸内海}

島々の景観には殆ど変化がないと考えられるが、瀬戸内海沿岸部 は寸でに戦中から産業施設が建設され（三菱重工業広島造船所江波 工場、観音工場など)、戦後には更に広島空港、東洋工業宇島工場、 出島の工場群などの新設に伴い大きな変化が見られる。

第一段階には瀬戸内海沿岸部でバスを停車させ、車内から島々を 眺望する。第二段階には新設の広島空港での下車を優先したため、 この沿岸部までの南下は省略される。しかし、第三段階には再度沿 岸部まで南下寸る運行系統となり、島々の案内がされる。

また、第一、第二、第三段階全てにおいて、比治山の展望台で下 車をして、瀬戸内海の島々、沿岸部の工業施設など、多くの対象物 を眺望する。第一段階（写真 14）、第三段階（写真 15）には沿岸部 で眺望対象とした幾つかの島を比治山山上から再確認する。第二段 階においては、沿岸部での案内の省略を補うかのように山上から多 くの島々が案内される。 


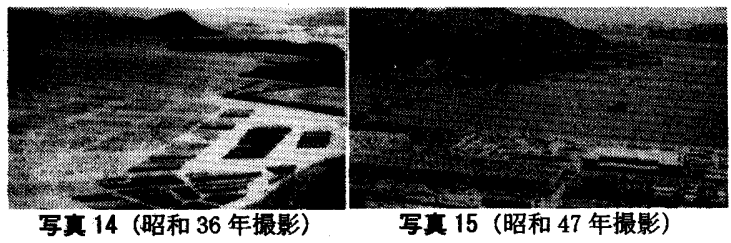

\section{3-9. 比治山}

全ての段階において、比治山に到着前に麓付近を走行中に特徽的 な山の形などが示された後、バスで登山道を通って、展望台近くで 観光客は下車する。篓付近からは窓一杯に山が見えており、建物の 高層化がさほど進んでいないことが伺える。

また第一段階には、比治山山上の北部分にある明治時代の政治的 建物跡である御便殿跡の西端の展望台で下車していた（写真 16）。 しかし、その展望台は桜の木々の繁茂によって眺望の悪化を招いた ため、第二段階には山の西部分に突き出た新設の富士見展望台へと 移り、第三段階にもこの展望台からの案内であった（写真 17）。

一方で、中心市街地からは比治山がよく見通せたと思われるが、 中心市街地からの案内はどの段階にもされない。

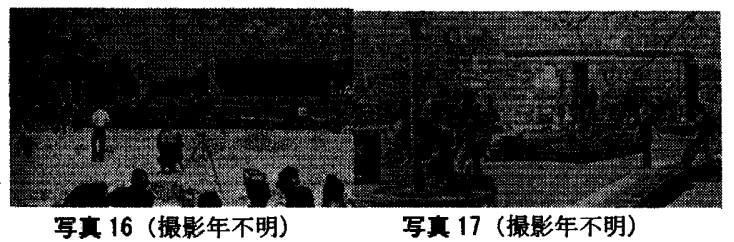

\section{4. 来内内容の経年索化（表 1-2 及び表 2 参照）}

\section{4-1. 世界平和記念是堂}

第一段階の初期には案内されないが、後期以降、第二、第三段階 では近くの橋の上から塔の上の十字架を示しながら、「世界各地の力 トリック信者や平和愛好者から集められた浄財一億円を以って着工 され、…という建設時の奇付や東洋有数の大聖堂の高さ、内部の 様子について、また平和への新りを捧げる象徴であると説明される。

また、「デルタの街、広島が一目で見渡せるあの塔の上から…」と いうように、市街地の俯瞰を示唆する説明が第二段階にされる。建 物の高層化によって、市街地の高い場所から俯㒈するという新しい 眺望を獲得したため、実際には塔の上に行かないにも関わらず、そ こからの俯瞰景について案内がされるようになったと考えられる。

しかし、第三段階にはこの案内はされなくなる。おそらく徐々に 周辺の建物高層化が進み、市街地を見渡せる公共建築物や商業建築 物が他にも見られるようになったことにも関連すると思われる29)。

\section{4-2. 靕貫圆}

縮景園は第二、第三段階にのみ、車中で確認できる少しの間に案 内される。第二、第三段階共に「元和六年芸州広島四十二万石のお 殿様、浅野長是公が支那現在の中国にある西湖の真似をして造られ たもので、浅野の泉邸とも呼ばれております。」という作庭について の歴史的な内容も含む庭園の概要が説明される。また、第三段階に はそれに加えて、被爆樹木が残っていることが説明される。

しかし第三段階には、庭園内の小高い丘から「瀬戸内海が昔見え

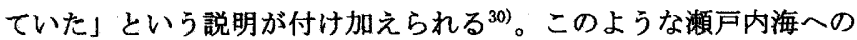
歴史的な眺望の案内は、第二段階から第三段階に入り、瀬戸内海沿
岸まで南下する運行系統に変更され、瀬戸内海への眺望の機会が増 したことにも関連していよう。

\section{4-3. 広岛城}

第一段階には、城内での大本営跡、通信司令室（防空壕）、練兵場 などの戦時中の施設の説明に加え、再建された天守閣から原爆ドー ムや軍事施設、被災地域が見えることが説明されている。

しかし第二段階以降は、移築された広島護国神社や、三百七十年 前の築城計画などの城の概要や戦時中に城を中心に多くの兵営があ ったこと、現在の天守閣の郷土館としての用途や城内の施設などの 案内人と変わる。これは、昭和 33 年の広島復興大博覧会の開催前に、 天守閣の復元や護国神社の再建などの城内の施設整備が進んだこと により、それらに対する案内が、戦時を示す対象物への案内よりも 優先されたためと考えられる。

\section{4-4. 原蛆ドーム}

第一段階には、ドーム内で被爆者によって「僕は 8 月 6 日午前 8 時 15 分には東を向いて手をこんなにしてたから、こうやけどしまし た」という生々しい体験話がされていた。

第二、第三段階には橋の上のバス内でのバスガイドによる案内 ${ }^{31}$ に変わり、内容も変化した。被爆前の広島県産業奨励館としての建 物の概要、「想い起こせば十七年前、昭和二十年八月六日、…と始 まる原爆ドームを中心とする市街地の被災状況、原爆投下後の周辺 の人々の様子（「母は子を求め、子は母を、夫よ妻よと、泣き叫ぶ、 修羅の巷と変り、…」）についての案内人と変わり、実体験からやや 遠いものになっている。

\section{4-5. 平和祀念公目}

平和記念公園は整備中であった時期を含めて、おおむねすべての 段階で「資料館の一階、中央の柱の間を通して、この慰霊碑と、原 爆ドームは、一直線に結ばれて居り、構成の美しさを誇って居りま す。又あちらの記念館と後の原爆ドームとこちらの公会堂を直線で 結びますと資料館を底辺とする三角形が出来上ります。…れらの 建物を結んで出来た三角形は、広島を表している訳でございます。」 というこの公園計画を誇る内容の説明がされる。

しかし第三段階には、公園敷地の整備前の町の様子について、「広 島で一番賑やかであった場所、それが今の平和公園です」といら説 明が付け加えられる。第一、第二段階はそれぞれ公園整備中、完成 直後であり、新しく整備され話題性の高い平和記念公園についてそ の計画や形態の紹介が中心となったため、公園敷地の整備前につい ての案内はされなかったと考えられる。しかし第三段階において、 戦前のこの地域の都市における中心的な繁街であったという重要 性から、公園敷地の整備前の説明が加えられたと考えられる。

\section{4-6. 広岛空港}

第二段階のみで下車案内される。到着前には、「…滑走路と $\cdots$ 大き さを誇る空港ビルが、青い内海とはえて快い調和をみせている近代 的な飛行場です。」という規模などを誇る案内や今後の拡張計画など についての説明がされる。出発後には、「最近は「瀬戸内海の眺めは 空から」と航空会社もしきりに宣伝しております」という、飛行機 によって初めて得られた瀨戸内海の眺めを示唆する説明がされる。

また、比治山展望台から俯瞰して案内される。第一段階の初期に はまだ完成していないため案内されないが、第二段階では全ての眺 望対象を経由、案内した後に、比治山から「皿山の向う側に、国内 
旅客航空機の発着する広島飛行場があります。」という簡単な再確認 がされる。新しい交通手段の獾得により、話題性が高かったため、 再度案内されたものと考えられる。

\section{4-7. 東洋工集宇品工堨}

第二段階の昭和 37 年には東洋工業宇品工場の操業開始後を想定 して、ガイドテキストには案内の記述があり、操業が開始される昭 和 41 年以降、ガイドテキストに沿って比治山展望台から案内され る。産業施設の象徴として、「大きな煙突が沢山立ち並んでいる所は」 と指し示され、「マツダオート三輪、マツダクーペの製造で、全国に その名を知られております」というその生産力を誇る説明がされる。 工業化が盛んな時代であることがわかると同時に、戦後復興の象徵 としての意味も含意されていたと思われる。

\section{4-8. 濑戸内海}

瀬戸内海は、市街地南部の瀬戸内海沿岸周辺と、比治山の山上か ら案内される。

市街地南部からは、第一段階には車中で「ここからも、島が見え ます。似の島の話をして、風光明媚な瀬戸内海でここからどこ行き の船が出ますよ。宮島は平清盛が 1300 年に建てたものですよ」など の宮島も含めた島々の歷史などが説明される。さらに、第三段階に では島の戦時中の用途（似の島の陸軍の検疫所など）や現在の用途 （似島学園など）の説明が付け加えられる。

比治山の展望台からは、島々の案内が殆どであるが、第二段階に 特に多くの島々が案内される（3-8. 参照）。「藤原時代の華やかな美 しさを伝え残して」いる宮島の㛜島神社や、「戦前は、多くの海軍将 校を生んだ、海軍兵学校の所在地として有名」な江田島、「平家の御 大将、平の清盛公が切り開かれたと伝えられて」いる音戸の瀬戸、

「戦前数百万屯の艦船を㩲し、列国海軍に互して、帝国海軍として の偉容を誇って」いた呉市などの説明がされる。この他にも、宇品 港の戦時中の軍港としての役目など、様々な年代の歴史的な説明が 多くされる。瀬戸内海沿岸の施設について第二段階には三菱造船所 や、新設の東洋工業宇品工場、広島空港の説明が増える。

このように瀬戸内海に関しての案内は、三つの段階を通して、自 然景観としての案内はもちろん含まれるが、特に島々などに関わる 戦前の様々な時代の史実についての説明が多くされる。運行系統全 体の中でも、戦前の歴史的な説明は特に瀬戸内海の島々において多 くされており、眺望対象としての重要性が同える。

\section{4-9. 比治山}

比治山についての案内地点は変化せず、麓付近と登山道、及び山 上で案内される。

内容については、山の麓付近ではどの段階でも昔は瀬戸内海に浮 かぶ島であったこと、山の南側には貝塚が残っていること、頼山陽 が「虎が伏した山“がこ山”」と名付けたことなど歴史的な説明がさ れる。特に第二段階のみで、こうした説明に後に「何かしら時の流 れを感じさせられるのでございます」という過去との慗がりを強調 する説明が加えられる。

さらに第二段階には登山道で、第三段階には山の麓付近で、「桜の 名所」「市民の嚊いの場所」など現在の様子についての説明がされ るようになる。一方、どの段階にも登山道では、「広島で一番見晴 しの良い所です」や、「この眺望の素晴らしさは、一目百万ドルと云 われて居りまして‥」などと比治山からの眺めを誇る案内が殆どで
ある。その中でも、登山中に、第一、第二段階では「眼下に展る広 島の眺望をしばらくの間お楽しみ下さいませ」という説明があった が、木々の繁茂により第三段階にはなくなる。

また第一段階には、案内地点は定かではないが、比治山山上での 下車場所となる御便殿跡について、明治時代の政治的建物跡である ことなどの説明がされる。その後、第二、第三段階には下車場所は 御便殿跡よりも眺望の良い、新設の西側展望台一と移り、御便殿跡 についての説明はされなくなる。

このように比治山に関しては、この戦後復興期全体を通して眺め の良さや市民の悡いの場所という現況の説明だけではなく、山に関 係する史実や史跡などについての歴史的な説明も多くされている。

\section{5. おわりに}

以上より、バスガイドによって語られた広島市の観光景観をみて いくと、新設の高層建築や飛行機という新しい交通手段によって得 られた都市や瀬戸内海に対する俯瞰を強調する一方で、広島城や比 治山という戦前からある眺望による歴史的な意味を含む俯瞰景は継 続的に取り上げられ、重要視されていることがわかる。

また、戦後に再建もしくは新築された施設については、当初は戦 後復興という意味が強調されているが、その後、戦前からの歴史も 含めた案内がされ、歷史的な熬がりが説明されるようになる（特に 平和記念公園、縮景園、広島城)。逆に戦争の史実が途中から取り上 げられるものもある(瀬戸内海、比治山)。

これらのことは、地元のバス会社による郷土愛の反映ともいえよ うが、単に戦後復興を示すために対比として語るために戦前の歴史 が取り上げられたのではない。戦前の広島の伝統、戦中のむしろ語 りたくはないであろう史実、そして誇るべき戦後復興が定期観光バ スにおける語りにおいて慗がれていく。つまり、原爆投下によって 破壊された都市広島では、都市環境が急激に変化していく戦後復興 期に、おそらく物理的な復興の様子を見に来たであろう㓋光客の要 望に応えるだけではなく、伝統的な俯瞰景や史実のある場所を通し て、歴史的な時間の連続性を復興し、都市環境全体の時間的・空間 的つながりの中で語り手は「平和」を志向し、聞き手の観光景観が 形成されていったと考えられるのである。実際、昭和 37 年のガイド テキストでは、「復與の息吹に然える広島の観光に、ようこそお越し 下さいまして、有り難うございます」に始まる定期観光バスは、最 後に比治山を経由し、歴史的都市環境全体が俯瞰され、「縄文文化の 昔から、現在まで、広島の歴史は、種々様々の人生をのせて、一秒 一分と年代を重ねています」という文言で締めくくられている。

しかしながら、観光景観におけるそうした歴史的な時間の連続性 は、高度成長期以降切断されていくことになる。この点に関しては、 次稿にて報告したい。

话等

本研究は広島バス株式会社の方々とそれに関係する方々の協力のもとに行 いました。ここに記して、感謝の意を表します。

军克出典 :

军真 1 : 広島市: 被爆 50 周年 図説戦後広島市史 街と暮らしの 50 年, p. 81, 1996. 3. 31

写賣 2 : 広島県立図書館 : 広島県立図書館要臨，p. 47, 1961.5

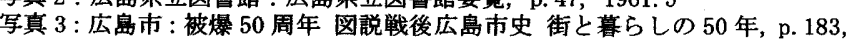
1996. 3.31

写真 4 ：広島市：河岸の戦後史 4 本川, p. $54,1988,3.31$

写真 5 : 広島市 : 広島被爆 40 年史 都市の復興, p. 74, 1985.8.6 
写真 $6:$ 広島市: 被爆 50 周年 図説戦後広島市史 街と暮らしの 50 年, p. 140, 1996. 3.31

写真 7 : (有)備後圈企画社 : 広島県の観光 ガイド写真集，p. $82,1974.12 .10$

写真 $8:$ 広島市: 広島被爆 40 年史 都市の復興, p. $94,1985.8 .6$

写真 9 : 広島市: 被爆 50 周年 因説戦後広島市史 街と暮らしの 50 年, p. 62 , 1996. 3. 31

写真 10 : 広島市 : HIROSHIMA 広島, p. 13，1973. 4

写真 11 : 広島市 : 河岸の戦後史 2 京橋川, pp. 64-65，1986.3.31

写真 12 ：段原公民館鄉土史クラブ：黄金山をめぐる郷土誌，p. 71，1988. 5.3

写真 13 : 段原公民館郷土史クラブ: 黄金山をめぐる郷土誌, p. 70, 1988.5 .3

写真 14 : 榔土出版社 : 広島市今昔写真帖 20 世紀のふるさと 150 景, p. 2, 2003.11.30

写真 15 ：段原公民館郷土史クラブ : 黄金山をめぐる郷土誌，p. $68 ， 1988.5 .3$

写真 16 : 中国新聞社 : 写真で見る広島あのころ, p. 154, 1977.8.15

写真 17 : (有)備後圈企画社 : 広島県の観光 ガイド写真集, p. 84, 1974.12.10

住： *本穆でのガイドテキストの引用はすべて原文のままである。

1) Garrett Eckbo : The Landscape of Tourism, Landscape, Vol. 18., No. 2, pp. 29-31,1969 では、そうした近代の観光景観の無場所性について論じて いる。

2) 観光景観における再現性の問題については、西村孝彦 : 文明と景観，地人 書房, 京都, 1997 参昭

3）広島市は、三角州上に登達した都市であるため、他の公共交通機関よりも バス路線が充実し、明治 36 年に日本で最初にバスが走った街として知られ ている。広島市における定期観光バスは、広島バス株式会社（以下、「広岛 バス」）によって昭和 29 年から運行されている。バスガイドの同行する観 光バスは昭和 2 年 12 月 2 日に大分別府の「英の井バス」から始まり、その 成功を受けて全国の観光地や都市でその形態を参考に次々に運行されるよ うになった（重信幸彦・大月隆宽：耳の旅の経験一昭和初期・別府龟の开 バス「少女車掌解説付地獄巡り」から, 旅の文化研究所 研究報告 4 号, pp. 1-13，1996. 12 参照)。現在、広島市における定期観光バス事業は、広 島バス 1 社のみによる運営であり、全国的に見てもその規模は大きくない。 しかし、広島市での定期観光バス事業導入は大分での成功を比較的早く取 り入れたものであるという（広島バス株式会社の事業者（総務部長 Y 氏、 観光部長 $\mathrm{N}$ 氏 社本社)。また、広島定期観光バスでは、事業開始時から現在まで長短の 2 コースから選択できた一時期を除いて、広島市内のみを回る1 コースと宮 島との組み合わせで幾つかのコースがあるのみである。おそらく広島が、 滞在型観光地ではなく、通過型観光地であるためであろう。本稿では、特 に広島市内のみを回る 1 コースを対象とした。

4) 千代章一郎・横山尚 : 広島定期観光バスにおける運行系統の変容, 日本都 市計画学会都市計画論文集，№. $38-3$, pp. 685-690，2003. 10

5) 本研究での「眺望対象」とは、観光客が説明されて見るものだけではなく 実際に見えなくても目を向けるという意味で、案内される全ての対象物之 して幅広く捉えている。

6)千代童一郎・横山尚：広島定期䔘光バスに㧍ける眺望対象の変容，日本建 策学会計画系論文集, No. 581, pp. 227-234, 2004.7

千代章一郎・横山尚：事業開拓期の広島定期観光バスにおける眺望対象, 日本都市計画学会都市計画論文集，No. 39-3，2004.10

7)本稿の分析では、主要眺望対象によって得られる観光景稓の変要を分析す ろため、所謂「シークエンス景」について主題的に考察していない。シー クエンス景については、馬木知子・吉村晶子 : 迴遊式庭園にみる風景生成 に関する研究, ランドスケーブ研究, Vol. 63, No. 5, pp. 573-576, 2000 ; 加藤祐介・吉田博宣 : 史跡岡城跡におけるシークエンス景観の分析, ラン ドスケープ研究，Vol. 67，No. 5，pp.637-642，2004などの分析があるが、 これらの研究では、景観の歴史的変容については考察されていない。本穆 では観光固観の時閒的変容を、上り重点的に考察しようとするものである。 8) この戦後復興期の定期観光バスの客層は、バスガイド経験者へのインタビ ユーによる。職場で団体でいらしたり、修学旅行でいらしたり、原爆に興 味を持って、戦後どのように復興したかっていらのもニュースで流れたら、 訪ねていらしたり」「当時は忛っこう新婚旅行もありましたね。宫岛があ りましたから。」(注: 21) 参照) 客層は一年の中でも時期によって異なり また年代による変化があるが、そういった変化に伴ったガイドテキストの 内容の変更などはせず、どんな客層にも対応できるように特化しないよう に作成している。したがって、さしあたり観光客が形成する観光景観は当 時の客層の変化に左右されないと考えられる。(注 : 3) 参照)

9) 姬野由香・佐藤誠治・小林祐司・金キョン希：観光資源が写された景観画 像の構図解析手法，日本建築学会計画系論文， No. 569，pp. 139-145, 2003.7

10)神谷文子・浦山益郎・北原理雄：主題要素の写され方からみた都市景短写 真の構図に関する研究 欧米 10 都市の観光ガイドブックを事例として, 日 本建築学会計画系論文集, No. 528, pp. 179-186, 2000.2

11) 千葉一輝 : 江戸・東京に拈ける眺望の変容に関する研究, 日本建築学会計 画系論文集，No. 481，pp. 157-166，1996.3

12）青木陽二: 明治期比訪れた欧米人の風景記述，環境情報科学論文集，第 12 回, pp. 59-64, 1998

13）森田義規・羽生冬佳・十代田朗 : 明治以降戦前までの東京案内本の記載情 報の変遷，観光研究，日本観光研究学会，Vol. 15, No. 1, pp. 11-18, 2003. 10

14）西田正憲 : 瀬戸内海における定数名所・観光地等の変遷，ランドスケープ 研究, Vol. 61, No. 5, pp. 395-400, 1998

15) 八城薰・小口孝司 : 観光地選考に及ぼす個人的原風景と心理的個人差, 観 光研究，日本観光研究学会，Vol. 15, No. 1, pp. 27-33，2003.10

16）ガイドテキスト作成にあたり、バスガイドなどの作成者の意図によって、 案内が偏ることのないように広島市について広く案内ができるテキスト内
容にしていた。このことは、以下のバス会社の事業者へのインタビューに よって明らかである。「浅く広くその地域の昔からの文化というものを、よ り多く人に知って頂けるといら努力はしています。」(注：3）参照)

また、約一年おきにガイドテキストの内容の見直しを行なうが、一回の 印刷冊数が多いため、それがなくなるまで、又仕大きな運行系統の変更が 行なわれるまでは同じテキストに個人で加筆して使用していた。そのため、 現存するガイドテキストの発行年も 3 年から 9 年の間隔があいている (注 19）参照）。しかし、本稿で用いた昭和 37 年、48 年のテキストも含め、現 存するガイドテキストの内容は観光案内の大きな変化を十分追うことがで きるものであることは、S女史（注：21）参照）に確認娍みである。

また、この定期観光事業開始直後の時期には、バスガイドも業務に慣れ ておらず、作成されたガイドテキストの記述内容については、そのまま殆 ど手を加えずに案内していたと思わ㧈る。したがって本稿では、バスガイ ドによる「語り」の分析は、主にガイドテキストに依拠しており、「語り」 のコンテクストやニュアンスについては、考察の対象としていない「語り のダイナミズムについては、大隆宽: バスガイドの「語り」と観光の空 間，旅， No. 918， p. 60-62，2003.7 参照。

また、この時期には観光案内においてバスガイドと観光客が双方向的に コミュニケーションをとる対話型がとられていたが、その後、一方向的な 解説型へと移っていく。ただし、本稿ではそういった語りの型については 分析対象としていない

17) 広島市における観光案内では、平和に関する観光対象の性格上、政治的、 倫理的な問題が含まれることが多く、観光客から苦情を受けることがある ため、基本的にバスガイドはよく推嬗されたガイドテキストの内容に忠実 に案内を行なう。したがって、ガイドテキストとバスガイド経験者へのイ ンタビュー聴取データを同等のデータと捉え、共に一次资料として扱った。 18) 広島バス株式会社 : 観光案内テキスト市内編, 昭和 48 年 2 月 又株式会社: 観光案内(広島都心編), 昭和 57 年 1 月/ 広島バス株式会 社: 観光案内テキスト(広島市内編)，昭和 60 年 3 月 1 日/広島バス株部 ガイド教育センター:広島市内，平成 3 年 3 月 1 日 / 広島バス株式会社ガ イド教育センター：定期敏光テキスト，平成 11 年

19) 広島バス株式会社 : 観光案内テキスト (市内編)，昭和 37 年

20)広島バスのバスガイド退職者組織「安芸カイドクラブ」へのアンケート結 果、定期観光バス事業開拓期のバスガイド経験者が十名程度存命であるこ とが礁認できた。しかし、その組織在籍のバスガイド退賤者らは、すでに 当時の観光案内に関して記憶が少なかった。本稿ではよりその記憶が強く 残っている経験者二名に限定してインタビュ一調査を行った。(平成 15 年 10 月 19 日、12月 3 日、平成 16 年 3 月 10 日)

21)インタビュー対象者二名の経歴は以下の通りである。N女史は、昭和 26 年入社、定期観光事業開始の昭和 29 年に車掌からバスガイドに転向し， の後昭和 35 年まで広島市内の定期観光バスで乗務していた。また、S 女史 は昭和 35 年の入社直後は広島定期観光バスには短期間しか乗務しなかっ たが、その後昭和 40 年〜 41 年にガイド教育者として、定期観光バスのバ スガイドの教育を行っていた。したがって、前者は昭和 29 年〜35 年、後 者は昭和 40 年 41 年につての定期観光バスについてのインタビューを行 った。しかし、記憶が㖟昧な部分も多く見られたため、他の资料などを用 いて当時の様子については推測し、本文中にはそれを明記している。

22) 当時の観光景観を写真資料は、中国新閵社、広島市立中央図書館、広島紫 立図書館、広島市公文書館を中心に収集したが、眺望地点（視点場）之眺 望対象 (視対象) が一致する正確な资料は稀少である。本稿では、これら の写真資料队地形図・空中写真を用いて総合的に考察し、当時の観光景観 について復元している。

23)バスガイドへのインタビューによると、もっとも聖堂の近くを通らない運 行系統での運行は短期間であり、変更後は第二段階のようにこの聖堂を眺 望対象としていたらしい

24）第三段階に観光客が維景園をどのように見ていたかについてはバスガイ ドの記憶が定かではないため、推測の域を出ない。本文中の写真から、第 二段階と同様の方法では眺望できなかったことが伺える。

25）原爆ドームと呼ばれ始めた年代は明確ではないとされている。（広島市 被爆 50 周年 ヒロシマの被爆建造物は語る, p. 28, 1996.3.31 参照)

26)バスガイドへのインタビューによると、行政からの要請によって広島空港

で下車することになった。しかし、当時空港は珍しく、またお土産の販売 もされており、観光客は自由時間を最大限使っていた。

27)この運行系統は既に路線に交通量が多い時期にも関わらず設定されたも のであると考える。この広島空港は当時空港の少ない中国地方では珍しく、 また国内主要空港に位置づけられるほどの規模を持つ空港であったため話 題性が高く、交通量が多いにも関わらず、経由地とされたと考えられる。 28）東洋工業宇品工場は、他企業の工場用地を貿収した部分と、埋め立てをし た部分の隣り合った二箅所に建てられた。この第二段階は埋め立て工事の 途中であるため、この段階で眺望対象となっていたのは、他企業の工場跡 地である可能性もある。しかし、バスガイドへのインタビューによると ガイドテキストは先を見越した内容とすることもあるため、完成した工場 を想像して作成したと考えられる。

29)昭和 37 年までに広島地方第一合同庁舎をはじめ官庁街が形成され、天满 屋 (昭和 29 年) や福屋のデパート (昭和 4 年開店、昭和 21 年営業再開) も新筑されている。

30)縮景園からの瀬戸内海への眺望の歴史は、筧文三年（1663）京都の儒者黒 川道祐が編述した『芸備国郡志』に「策山に上ると東南に蓄海を眺め、瓶 島の山なみも拝することが出来る。と記述されていることからも確認され る。広島県教育委員会 : 縮景園史, pp. 8-9, 1983.3.31 参照。

31) バスガイドへのインタビューによると、下車案内よりも停車しているバス の中での案内の方が、観光客がバスガイドの案内に集中することができた。 